\title{
The Impact of Trade Unions on Employee Performance in Cameroon: Teachers' and Drivers' Unions Cases
}

\author{
Fanso Collins Dinyuy ${ }^{1}$ \\ Uğur Şener ${ }^{2}$
}

\begin{abstract}
The intention of this research is to examine the impact of trade unionism on employee performance in Cameroon. The teachers and the drivers trade unions are selected as the scope of the study. Both quantitative and qualitative data are collected with questionnaires and structured interviews. Categorical data was analysed as proportions and frequencies and the relationship between categorical variables was assessed using Chi-Square test. The findings revealed by the study evidently show that trade unions play a vital role in employee-performance in Cameroon. It is revealed in this research that, the key reason teachers and drivers joined trade unions in Cameroon is for the protection of workers' rights. The main strategies used by trade unions are organising, collective bargaining, alliance building and action. It was also revealed that trade unions have as core mandates, the promotion and protection of the rights and the socioeconomic interest of their members. Therefore, as a recommendation, Trade Unions should stay away from confrontation with employers and make negotiations for collective bargaining. Also, employers should provide upskilling and training opportunities to their employees as this improves employee-performance. Conclusively, Teachers and Drivers' Trade Unions in Cameroon should set as its top priority, the protection of workers' rights and promotion of their socio-economic interests.
\end{abstract}

Key words: Trade Union, Employee performance, Cameroon, Chi-square, Anglophone crisis

\footnotetext{
${ }^{1}$ Institute of Graduate Sciences, Business Administration (in English) Program, Istanbul Aydin University, Istanbul, fansocollins@gmail.com, Orcid: 0000-0001-5524-1707.

${ }^{2}$ Dr. Istanbul Aydin University, Faculty of Economics and Administrative Sciences, Department of Business Management (in English), usener@aydin.edu.tr, Orcid: 0000-0001-5524-1707

* Research Article. Received: 15.06.2021, Accepted: 09.07.2021.

DOI: 10.17932/IAU.FCPE.2015.010/fcpe_v07i2002
} 
The Impact of Trade Unions on Employee Performance in Cameroon: Teachers' and Drivers' Unions Cases

\section{INTRODUCTION}

A trade union is defined as an everlasting partnership of employees or salary earners for the aim of preserving or ameliorating their working conditions. According to TUC-RLF (2012), A trade union or worker's guild is likewise a partnership of employees to reinforce their efforts in haggling with their employers.

Throughout history, trade unions have fought for security and augmentation in wages, occupational safety at the workplace (by protecting members from unjust expulsion), wellbeing and good working conditions for their members. Trade unions in the African continent are not excluded in the quest for these priceless goals. Collective bargaining is the main tool utilized by trade unions be it at the level of the firm or at the national level. Trade unions are equally involving in persuading state bureaus for law enactments which favour employees and their families (Jones, Derek and Takao Kato, 2005).

The fundamental motivating force for establishing or being part of a trade unions and striving for collective bargaining is consequently to make even or somehow lower the imbalance of power among employers and employees (Jepkorir, 2014). Through this, trade unions are capable of breeding even-handedness, equity, impartiality, consideration for human right and workers' privileges, and communal and economic equity not focusing just on the workplace in particular but also significantly, in the community at large. This is because, individually employees, are not powerful enough to request for their privileges at the workplace. Also, there is enormous power and mutual benefits in communization and unity of workers (Clark, Kristensen, and Westergard-Nielsen, 2006).

The political, social and economic growth of the African continent has been greatly influenced by trade union activities. Trade unions in Africa were greatly involved in the fight for self-governance on all parts of the continent in the 1960s. Nonetheless, the labour movement in Africa has been experiencing many intimidating confrontations in their attempt to safeguard workers' rights and the rights of the substandard, unprotected, and vulnerable in the society since the 1980s and 1990s. The density of trade unions remain low in most African countries and union membership 
has been decreasing because of the fast rate of casualization and informal characters of work (Budd, John W. and Bhave, Devasheesh 2008).

According to Mbide (2014), the regime of Cameroon after gaining selfdetermination in 1960, had endorsed in 1962, the I.L.O. Treaty No. 87 of July $10^{\text {th }}, 1948$ which enforced the right to partnership, as well as I.L.O. Treaty No. 98 of June $8^{\text {th }}, 1949$, on the immunity to coordinate as well as negociate unitedly. Freedom of association is guaranteed, giving employees and employers the right to form trade unions and employer's associations respectively as prescribed by the Labour Code. Since obtaining sovereignty in 1960, Cameroon has created about three Laws initiating the Labour Code which permitted right to associate and the privilege to formulate and negotiate collectively. The International Labour Organization, (ILO), Treaty No. 87 articulates in unit 2 inter-alia, "Workers and employers, without distinction whatsoever, shall have the right to establish and subject only to the rules of the organization concerned, to join organization of their own choosing without previous authorization." Cameroon has a wealthy and telling past concerning the labour movement. Before and after independence, Cameroon was characterized with a good number of freebie sovereign trade unions, most of these unions were found in the estates within West Cameroon. We also had a good number of trade unions in East Cameroon for instance Union des population du Cameroun (UPC) which transformed into a political party (Adesina, 2000).

From this background, this study, therefore, targets to explore the role of trade union on employee performance in Cameroon. In addition, we shall identify the reasons for joining trade unions and the core mandates and strategies towards improving employee performance within the Teachers and Drivers Unions in Cameroon. 
The Impact of Trade Unions on Employee Performance in Cameroon: Teachers' and Drivers' Unions Cases

\section{LITERATURE REVIEW}

Trade union existence bears statistical and economical important influence on employee performance and organizational productiveness (Morikawa 2010). Worker performance and overall productivity are mostly associated with good employee abilities, encouragement, and good management. Conforming to McNicholas et al. (2020), trade unions are helpful as they reduce exploitation of workers and also counteract the firm's monopolistic strength. To satisfy short and long-term objectives, corporations want to have efficient and good workers together with good cooperativeness amongst the administration and workers. If union problems are solved harmoniously and rapidly, improved performance of workers can be achieved in organizations (Nkirote, \& Kiiru 2018). Broadly, it's not common to keep a great relationship between the administration and employees in bigger associations. Hence, workers turn to create trade union when they feel that there is little or no real connection between them, and the administration and attention are not given to their worries. In Cameroon just like other nations, initially, trade unions are created to boost collective bargaining, in due course, they culminate with impacts on coherence and productivity.

Nevertheless, the impact of unions in all facets like promotion in organizations without unions are based on age instead of merit which is likely to hinder the performance and productivity caused by worker discontentment. Additionally, unions might pose an adverse effect by utilising the monopoly they enjoy to pressure for high salaries and to present malpractices that hinder performance. The effect of unions on topics such as traineeship and training procedures, advertising policies, organization of work, commission level, and obligations plan and grievances procedure will feed through productivity (Poil \& Knight, 2005).

Gunderson (2005) posits that combined with the renowned rent-seeking behaviour of unions, they may possess a favourable effect on performance by enunciating worker's worries, enhancing labour/management relationship, adding morale, and reducing overturn. antecedent work has proposed that this impact might be larger in the public sector as a result of growing devotion and diminished exit tendency of public workers.

Agood number of studies have not been able to find any connection between unions of public workers and organizational performance. There is no direct 
effect of unionization on the results fabricated by public agencies (Ash and Seago, 2004). It is worth noting however that, when combined with the growing disbursement related to unionization null operation gains for public corporations are often treated as adverse productivity consequences by scholars. Hoxby (2001), comparably found out that teachers' union increase their wages without a consequent upgrade in student performance. He deduced that trade unions were a potential reply to the puzzle of school spending more and slack pupil performance during the post-1960 era.

Unions affect the approach in which organizations react to economic fluctuations. Conforming to Freeman and Medoff (1988), in times of recessions, companies with unions have a tendency to utilize nonpermanent growth rather than reductions in salaries which is not the case in non-unionized businesses. In reminiscence, in recurrent upturns, companies with unions call back comparatively more workers and nonunion companies end up recruiting new workers.

\section{METHODOLOGY}

To better attend its goals, the research adopted a methodology that inspects the qualities of elements and the procedure and meanings that are not tentatively analysed or estimated. The quantitative and qualitative methods were combined to carry out this study. The study used, algebraic, mathematical and statistical investigative approach to deduce pertinent info from data that was assembled.

\section{Sampling Design and Data Collection}

The research population is defined as members of drivers' and teachers' unions in Cameroon. Convenience sampling technique is used in this study considering the cost of research and unavailability of sampling framework so our quantitative results cannot be generalised to population according to sampling technique employed. However, findings will supply strong suggestive insights for understanding the current situation and improvements to make it better. Primary data was collected by sending out questionnaires to teachers from all over the 10 regions of Cameroon, who came together during the assessment of the Cameroon General Certificate of Education (GCE) national examinations. We also handed out additional questionnaires to teachers in the towns of Yaoundé and Bamenda. The data collected from these teachers closely represent the 
The Impact of Trade Unions on Employee Performance in Cameroon: Teachers' and Drivers' Unions Cases

national territory since they came from different regions and also belong to different trade unions. Questionnaires were also given out to drivers in towns of Buea and Yaoundé in Cameroon. Although we did not use a probabilistic sampling technique which has strong generalizability, selected sample contains drivers and teachers from all parts of Cameroon for a considerable representation of the population. We reached total 308 respondents which are more than to ensure $90 \%$ confidence interval.

We aimed to have structured interviews with 20 trade union leaders and key members for the qualitative analysis of our research. Considering the current Anglophone Crisis in Cameroon, we decided to keep their names confidential. We collected qualitative data from ANCATC (l'Association Nationale Autonome des Chauffeurs d'Autobus, de Taxis et des Cars du Cameroun), CAPSU (Cameroon Public Service Union), CAPTAC (Confederation of Anglophone Parent-Teachers Associations), CATTU (Teachers' Trade Union), CNU (Cameroon National Union), CTUC (Cameroon Trade Union Congress), NUCW (National Union of Cameroon Workers), PEATTU (Presbyterian Education Authority Teachers Trade Union), SN CHAUTAC (Syndicat National Des Chauffeurs Taxis - Cars - Auto Bus et Assimilés du Cameroun), SYNDICAT (National Autonome de l'Enseignement Secondaire), SYNES (Syndicate of Teachers of Higher Education), TAC (Teachers' Association of Cameroon).

The questions were also evaluated by both academics and trade union leaders, and the comprehensibility of the questions was evaluated by conducting a pilot application with 10 people in a drivers and teachers trade unions. Participants stated that they did not have any problems in understanding the expression and content.

\section{QUANTITATIVE RESULTS}

About 358 questionnaires were distributed and 308 were answered and returned, giving a response rate of $86 \%$. Trade union representation was almost equal, with $156(50.6 \%)$ drivers and 152 (49.4\%) teachers. For qualitative part of the study, we did structured interviews with 19 trade union leaders (9 from drivers' union and 10 from teacher's union) from 15 different trade union organisations ( 8 teachers' unions and 7 drivers' unions). 


\section{Demographic Results}

Table 1: Distribution of Age Factor by Trade Union

\begin{tabular}{|l|l|l|l|}
\hline Age group & Drivers N (\%) & Teachers N (\%) & Total N (\%) \\
\hline$<20$ & $2(1.3)$ & $10(6.7)$ & $12(3.9)$ \\
\hline $20-30$ & $45(28.8)$ & $37(24.8)$ & $82(26.9)$ \\
\hline $31-40$ & $62(39.7)$ & $4630.9)$ & $108(35.4)$ \\
\hline $41-50$ & $42(26.9)$ & $33(22.1)$ & $75(24.6)$ \\
\hline $51-60$ & $5(3.2)$ & $23(15.4)$ & $28(9.2)$ \\
\hline Total & $156(100.0)$ & $149(100.0)$ & $305(100.0)$ \\
\hline
\end{tabular}

The majority of the respondents are between the ages of 31 and $40(35.4 \%)$, this implies that most of them are in the active age group and can perform better in their various jobs.

Table 2: Distribution of Gender by Trade Union

\begin{tabular}{|l|l|l|l|}
\hline Gender & Drivers N (\%) & Teachers N (\%) & Total N(\%) \\
\hline Male & $144(99.3)$ & $86(56.6)$ & $230(77.4)$ \\
\hline Female & $1(0.7)$ & $66(43.4)$ & $67(22.6)$ \\
\hline Total & $145(100.0)$ & $152(100.0)$ & $297(100.0)$ \\
\hline
\end{tabular}

The population was predominantly male $(77.4 \%)$, this implies that most of them are in the active age group and can perform better in their various jobs. Males comprised $56.6 \%$ of all teachers and there was only $1(0.7 \%)$ female driver. The disparity in gender gives an indication in terms of gender participation and belonging in trade union activities. 
The Impact of Trade Unions on Employee Performance in Cameroon: Teachers' and Drivers' Unions Cases

Table 3: Distribution of level of education by trade union

\begin{tabular}{|l|l|l|l|}
\hline Level of Education & Drivers N (\%) & Teachers N (\%) & Total N (\%) \\
\hline FSLC & $45(28.8)$ & $0(0.0)$ & $45(14.6)$ \\
\hline O Level & $41(26.3)$ & $3(2.0)$ & $44(14.3)$ \\
\hline A Level & $38(24.4)$ & $22(14.5)$ & $60(19.5)$ \\
\hline Diploma & $17(10.9)$ & $21(13.8)$ & $38(12.3)$ \\
\hline Bachelors & $14(9.0)$ & $62(40.8)$ & $76(24.7)$ \\
\hline Masters & $1(0.6)$ & $39(25.7)$ & $40(13.0)$ \\
\hline PhD & $0(0.0)$ & $5(3.3)$ & $5(1.6)$ \\
\hline Total & $156(100.0)$ & $152(100.0)$ & $308(100.0)$ \\
\hline
\end{tabular}

The largest proportion of respondents (24.7\%) had completed Bachelors's degree. Among drivers, most had just a First School Leaving Certificate (FSLC) (28.8\%), 9\% had a bachelor's degree while only 1 driver had a Masters. Teachers on the other hand were more educated with majority having a bachelor's degree (40.8\%). About $25 \%$ of teachers had a master's degree while $5(3.3 \%)$ had a PHD. This fact shows that both trade unions had workers who are literate and were able to read and understand the questionnaire.

Table 4: Distribution of Marital Status by Trade Union

\begin{tabular}{|l|l|l|l|}
\hline Marital status & Drivers N (\%) & Teachers N (\%) & Total N (\%) \\
\hline Married & $89(58.6)$ & $86(57.0)$ & $175(57.8)$ \\
\hline Single & $41(27.0)$ & $46(30.5)$ & $87(28.7)$ \\
\hline Cohabit & $14(9.2)$ & $11(7.3)$ & $25(8.3)$ \\
\hline Separated & $7(4.6)$ & $6(4.0)$ & $13(4.3)$ \\
\hline Divorce & $1(0.7)$ & $2(1.3)$ & $3(1.0)$ \\
\hline Total & $152(100.0)$ & $151(100.0)$ & $303(100.0)$ \\
\hline
\end{tabular}

Most respondents were married (57.8\%), followed by single people who comprised $28.7 \%$ of respondents. Equally, the majority of drivers and teachers were married, $58.6 \%$ and $57 \%$ respectively. Divorce was quite uncommon among respondents. 
Table 5: Distribution of Religion by Trade Union

\begin{tabular}{|l|l|l|l|}
\hline Religion & Drivers N (\%) & Teachers N (\%) & Total N (\%) \\
\hline Muslim & $65(42.8)$ & $18(11.9)$ & $83(27.4)$ \\
\hline Christian & $85(55.9)$ & $127(84.1)$ & $212(70.0)$ \\
\hline Pagan & $2(1.3)$ & $6(4.0)$ & $8(2.6)$ \\
\hline Total & $152(100.0)$ & $151(100.0)$ & $303(100.0)$ \\
\hline
\end{tabular}

The majority of respondents were Christians (70\%). Religion distribution does not change according to being driver or teacher.

\section{Involvement of Workers in Trade Unions}

Table 6: Involvement of Trade Union Members in Activities

\begin{tabular}{|l|l|l|l|}
\hline $\begin{array}{l}\text { Do you involve in trade union } \\
\text { activities? }\end{array}$ & $\begin{array}{l}\text { Drivers n } \\
(\mathbf{\%})\end{array}$ & $\begin{array}{l}\text { Teachers n } \\
(\mathbf{\%})\end{array}$ & $\begin{array}{l}\text { Total n } \\
(\mathbf{\%})\end{array}$ \\
\hline Yes & $145(93.5)$ & $103(68.2)$ & $248(81.0)$ \\
\hline No & $10(6.5)$ & $48(31.8)$ & $58(19.0)$ \\
\hline Total & $155(100.0)$ & $151(100.0)$ & $306(100.0)$ \\
\hline
\end{tabular}

Table 6 illustrates the involvement of respondents in trade union activities. $81 \%$ of respondents said they were involved in trade union activities. More drivers were involved in trade union activities (93.5\%) than teachers (68.2\%). This is expressive of their active participation, indicated by the sizeable proportion of workers who partake in trade union affairs. From the table more than $60 \%$ of respondents from both subgroups take active part in trade union activities confirming their willingness to involve in unions considering the positive impact it brings in their jobs.

\section{Reasons for Belonging to Drivers and Teachers Trade Unions in Cameroon}

The research objective aimed to identify reasons that motivate workers to join trade unions in Cameroon, besides legal provisions by the government allowing workers to legally form Trade Unions and the protection for their rights. Table 7 below presents the reasons why employees decide to be part of trade unions in Cameroon. Protection of workers is the commonest reason for joining a trade union, accounting for $65.9 \%$ of all reasons. Both drivers and teachers also chose "protection of workers" as their top reason 
The Impact of Trade Unions on Employee Performance in Cameroon: Teachers' and Drivers' Unions Cases

for joining a trade union, $71.8 \%$ and $57.7 \%$ respectively. The second most common reason was to "make one's voice heard" (17.5\%), which was also the second most common choice for both drivers and teachers. From the survey, majority of the respondents indicated that unions help to protect workers' rights, make their voices heard and also engage in collective bargaining. Concurring to the views of respondents, Gunderson (2005), asserted that in addition to the afore mentioned points, union actions will have a positive impact on worker-performance by granting voice to members concerns, increasing their morale and improving communication between the employers and worker.

Table 7: Reasons for Belonging to A Teachers or Drivers

Trade Union in Cameroon

\begin{tabular}{|l|l|l|l|}
\hline $\begin{array}{l}\text { What are your reasons for joining trade } \\
\text { unions? }\end{array}$ & $\begin{array}{l}\text { Drivers } \\
\mathbf{n}(\mathbf{\%})\end{array}$ & $\begin{array}{l}\text { Teachers } \\
\mathbf{n}(\mathbf{\%})\end{array}$ & $\begin{array}{l}\text { Total } \\
\mathbf{N}(\mathbf{\%})\end{array}$ \\
\hline Protection of workers' rights & $102(71.8)$ & $60(57.7)$ & $162(65.9)$ \\
\hline To make one's voice heard & $18(12.7)$ & $25(24.0)$ & $43(17.5)$ \\
\hline Collective Bargaining & $8(5.6)$ & $19(18.3)$ & $27(11.0)$ \\
\hline $\begin{array}{l}\text { Protection of workers' rights /to make one's voice } \\
\text { heard }\end{array}$ & $8(5.6)$ & $0(0.0)$ & $8(3.3)$ \\
\hline Protection of workers' rights /Collective Bargain & $1(0.7)$ & $0(0.0)$ & $1(0.4)$ \\
\hline $\begin{array}{l}\text { Protection of workers' rights /to make one's voice } \\
\text { heard /collective Bargain }\end{array}$ & $5(3.5)$ & $0(0.0)$ & $5(2.0)$ \\
\hline Total & $\begin{array}{l}142 \\
(100.0)\end{array}$ & $\begin{array}{l}104 \\
(100.0)\end{array}$ & $\begin{array}{l}246 \\
(100.0)\end{array}$ \\
\hline
\end{tabular}

\section{Understanding Strategies Used by Trade Unions to Promote Employee- performance in Cameroon}

Table 8 shows that the majority $(74.3 \%)$ of respondents agreed that organizing, collective bargaining, alliance building, and action are the key strategies for unionising, while $19.7 \%$ stood for plan, action and evaluation as the main strategy used by unions. $6 \%$ of the respondents said formulation, membership drive and power sharing are the main strategies used by trade union to achieve their objectives. Drivers were in more agreement than teachers that organizing, collective bargaining, alliance building, and action are the main strategies used by trade unions for attaining their objectives, representing $80.6 \%$ and $65.7 \%$ respectively. 
Table 8: Strategies Used by Trade Unions to Improve Employee Performance

\begin{tabular}{|l|l|l|l|}
\hline $\begin{array}{l}\text { What are Strategies used by } \\
\text { trade unions to improve employee } \\
\text { performance? }\end{array}$ & $\begin{array}{l}\text { Drivers } \\
\text { n (\%) }\end{array}$ & $\begin{array}{l}\text { Teachers } \\
\text { n (\%) }\end{array}$ & $\begin{array}{l}\text { Total } \\
\text { n (\%) }\end{array}$ \\
\hline $\begin{array}{l}\text { Organising, collective bargaining, } \\
\text { alliance building and action }\end{array}$ & $116(80.6)$ & $69(65.7)$ & $185(74.3)$ \\
\hline Plan, action and evaluation & $23(16.0)$ & $26(24.8)$ & $49(19.7)$ \\
\hline $\begin{array}{l}\text { Formulation, membership drive and } \\
\text { power sharing }\end{array}$ & $5(3.5)$ & $10(9.5)$ & $15(6.0)$ \\
\hline Total & $144(100.0)$ & $105(100.0)$ & $249(100.0)$ \\
\hline
\end{tabular}

\section{Core Mandates of Trade Unions in Cameroon}

Table 9 below discloses the core mandates used by trade unions in Cameroon to attain the goals of trade unionism. Data from Table 5 is analysed into two subsections; teachers trade unions and drivers trade unions.

For teachers, $78.1 \%$ of the respondents revealed that "promote and protect the right and socio-economic interest of workers" are the core mandates of trade unions, $14.3 \%$ of them said "fight for the needs of members at workplace" and $7.6 \%$ said "promote unity amongst members". For drivers, $78 \%$ of the respondents indicated that "promote and protect the right and socio-economic interest of workers" and $8.5 \%$ of them said "fight for the needs of members at workplace" are the principal core mandates of trade unions. While $13.5 \%$ were of the opinion that to "promote unity amongst members" is the core mandates of trade unions. 
The Impact of Trade Unions on Employee Performance in Cameroon: Teachers' and Drivers' Unions Cases

Table 9: Core Mandates of Drivers and Teachers Trade Unions in Cameroon

\begin{tabular}{|l|l|l|l|}
\hline $\begin{array}{l}\text { What are core mandates of Trade } \\
\text { Union? }\end{array}$ & $\begin{array}{l}\text { Drivers } \\
\mathbf{n}(\mathbf{\%})\end{array}$ & $\begin{array}{l}\text { Teachers } \\
\mathbf{n}(\mathbf{\%})\end{array}$ & $\begin{array}{l}\text { Total } \\
\mathbf{n}(\mathbf{\%})\end{array}$ \\
\hline $\begin{array}{l}\text { To promote and protect the rights } \\
\text { and socioeconomic interests of } \\
\text { workers }\end{array}$ & $110(78.0)$ & $82(78.1)$ & $192(78.0)$ \\
\hline $\begin{array}{l}\text { To fight for the needs of members at } \\
\text { workplace }\end{array}$ & $12(8.5)$ & $15(14.3)$ & $27(11.0)$ \\
\hline To promote unity amongst members & $19(13.5)$ & $8(7.6)$ & $27(11.0)$ \\
\hline Total & 141 & $105(100.0)$ & $246(100.0)$ \\
\hline
\end{tabular}

\section{Trade Unions and the Role they Play in Employee Performance}

Table 10 below presents the extent to which respondents agreed or disagreed that trade unions play a vital role in employee-performance in Cameroon. Overall, the majority (40.2\%) agreed, followed by $39.8 \%$ who were neutral about the role trade unions play on employee-performance. Only $0.8 \%$ of respondents disagreed.

For the teachers, $43.8 \%$ of the respondents agreed that trade unions play a vital role in employee-performance, $15.2 \%$ of them strongly agreed while only $1 \%$ strongly disagreed. Amongst drivers, most of them agreed (37.5\%), $42.4 \%$ were neutral while only $0.7 \%$ disagreed.

Table 10: To What Extent Do You Agree or Disagree That Trade Union Plays a Vital Role in Employee Performance

\begin{tabular}{|l|l|l|l|}
\hline $\begin{array}{l}\text { To what extent do you agree or disagree } \\
\text { that trade union plays a vital role in } \\
\text { employee performance }\end{array}$ & $\begin{array}{l}\text { Drivers } \\
\mathbf{n}(\%)\end{array}$ & $\begin{array}{l}\text { Teachers } \\
\mathbf{n}(\%)\end{array}$ & $\begin{array}{l}\text { Total } \\
\mathbf{n}(\%)\end{array}$ \\
\hline Strongly agree & $26(18.1)$ & $16(15.2)$ & $42(16.9)$ \\
\hline Agree & $54(37.5)$ & $46(43.8)$ & $100(40.2)$ \\
\hline Neutral & $61(42.4)$ & $38(36.2)$ & $99(39.8)$ \\
\hline Disagree & $2(1.4)$ & $4(3.8)$ & $6(2.4)$ \\
\hline Strongly disagree & $1(0.7)$ & $1(1.0)$ & $2(0.8)$ \\
\hline Total & $144(100.0)$ & $105(100.0)$ & $249(100.0)$ \\
\hline
\end{tabular}




\section{Determinants of trade union's role in improving workers-performance}

This section aimed to determine whether a relationship exists or not between understanding of employee performance and the demographic and trade union specific factors. A chi-square test of independence was performed to examine the association. The dependent variable was "does trade union membership improve workers performance?", while the independent variables were, demographic factors and trade union specific questions (Table 11). The analysis, therefore, seeks to identify independent factors that are associated with an improved employee-performance amongst teachers and drivers in Cameroon. The Chi-square results below are reported in the format $X^{2}$ (degrees of freedom, $N=$ number of responses) $=$ chi-square statistic value, $p=p$ value. From Table 4.7 below, age group, level of education and rating of strength of trade union were statistically significantly associated with improved employee performance.

We hypothesized that age group is related to improved employee performance. In our analysis, the relation between age and improved employee performance was statistically significant, $X^{2}(4, N=243)=$ $14.4, p=.006$. The test statistic (14.4) is greater than the critical value 9.5 from the Chi-square table, therefore we rejected the null hypothesis. There is a significant relationship between Age and employee-performance.

It is hypothesized that the level of education is associated with increased employee performance. The analysis showed a statistically significant association between level of education and improved employee performance $X^{2}(6, N=246)=15.3, p=.018$. From the Chi-square table, the test statistic 15.3 is greater than the critical value 12.5 , therefore we rejected the null hypothesis. People with a higher level of education have more skills and ability learn faster than those of a lower level of education, this is directly reflected as an improved employee-performance.

A higher rating of the strength of a Trade Union was hypothesized to be related to improved employee performance. This study showed a statistically significant relationship between higher rating of the strength of a Trade Union and improved employee-performance $X^{2}(2, N=237)$ $=13.9, p=.001$. The test statistic 13.9 is greater than the critical value of 6.0 based on the Chi-Square Table, therefore the null hypothesis was rejected. Rating the strength of their trade union high is associated with 
improved employee performance because powerful trade unions with a strong mandate and core strategies will improve the working conditions and protect its members creating better working conditions for them to be more productive and efficient, hence improving employee-performance.

However, a statistically significant association was not established between gender, marital status religion, duration of membership in trade union, level of confidence in your trade union representatives and other factors (table 11) with improved employee-performance. It was hypothesised that all other independent variables were associated with improved employee performance. However, based on Chi-square table comparison of Chisquare test statistic and critical value, the null hypothesis was not rejected for these variables. So, there was no statistically significant association between these other variables (Table .11) and improved employee performance. 
Table 11: Trade Union Factors Associated with Improved Worker-Performance.

\begin{tabular}{|c|c|c|c|c|c|}
\hline Variable & \begin{tabular}{|l|} 
Chi square \\
Calculated
\end{tabular} & df & Significance & $\begin{array}{l}\text { Chi Square } \\
\text { Table value }\end{array}$ & $\begin{array}{l}\text { Relationship } \\
\text { exists }\end{array}$ \\
\hline Gender & 0.39 & 1 & 0.532 & 3.841 & No \\
\hline Age & 14.4 & 4 & 0.006 & 9.488 & Yes \\
\hline Level of education & 13.275 & 6 & 0.018 & 12.592 & Yes \\
\hline Marital Status & 2.348 & 4 & 0.672 & 9.488 & No \\
\hline Religion & 3.001 & 2 & 0.223 & 5.991 & No \\
\hline $\begin{array}{l}\text { Do you involve } \\
\text { in Trade Union } \\
\text { activities? }\end{array}$ & 0.692 & $\mid 1$ & 0.156 & 3.841 & No \\
\hline $\begin{array}{l}\text { For how long have } \\
\text { you been the member } \\
\text { of Trade Union? }\end{array}$ & 9.459 & 4 & 0.051 & 9.488 & No \\
\hline $\begin{array}{l}\text { How will you rate } \\
\text { the strength of your } \\
\text { trade union? }\end{array}$ & 13.940 & 2 & 0.001 & 5.991 & Yes \\
\hline $\begin{array}{l}\text { How high is the level } \\
\text { of confidence you } \\
\text { have in your Trade } \\
\text { Union representatives? }\end{array}$ & 2.696 & 3 & 0.441 & 7.815 & No \\
\hline $\begin{array}{l}\text { Does belonging to a } \\
\text { union brings security } \\
\text { to life? }\end{array}$ & 2.540 & 4 & 0.638 & 9.488 & No \\
\hline $\begin{array}{l}\text { What is your level } \\
\text { of familiarity and/or } \\
\text { involvement with the } \\
\text { work and organization } \\
\text { of your Trade? }\end{array}$ & 3.459 & 4 & 0.484 & 9.488 & No \\
\hline $\begin{array}{l}\text { To what extent do you } \\
\text { agree or disagree that } \\
\text { trade union plays a } \\
\text { vital role in employee } \\
\text { performance? }\end{array}$ & 2.168 & 4 & 0.705 & 9.488 & No \\
\hline
\end{tabular}


The Impact of Trade Unions on Employee Performance in Cameroon: Teachers' and Drivers' Unions Cases

\section{QUALITATIVE RESULTS}

Since the study focused on two trade unions, it was imperative to get subjective insights from a trade unionist from both teachers and drivers trade unions. Some respondents revealed three common roles that trade unions play on employee performance in Cameroon. These were protecting employees against employer exploitation, collective bargaining, and maintain a cordial working relationship with their employers. To one of the trade union leaders, their trade union mobilises members for collective action especially in areas that concern negotiations for wages and better working conditions.

Thus, looking at the question of the role played by trade unions on employee-performance in Cameroon, the study equally revealed that when trade unions succeed to work out a deal for better working conditions and better wages, employee improved performance is guaranteed.

In conformity with some driver's trade union members and leaders questioned, trade unions play a pivotal role in worker-performance in several ways, which include union protects the right of employees, makes sure all workers work in accordance with the rules and regulation put in place, and brings unity among members and a platform where all their worries are tabled.

Still, on employee performance as a result of trade unionism, this research displays that performances of workers and overall organizational productivity increases when trade unions are well represented in times of disciplinary hearings and in times of grievances. A leader in his response cited situations where taxi drivers are either harassed or assaulted by Police officers in uniforms. He mentioned situations where some are locked up in prisons simply for having a misunderstanding with military personnel. It is for this reason according to his revelations, that such representation from the driver's union guarantee's that the results favour their members consequently motivating them to perform better.

\section{Challenges Faced by Trade Unions in Cameroon and how they Affect Employee Performance}

From the findings of the study, it was revealed that teachers' trade union(s) in Cameroon as articulated by the afore-mentioned interviewees face a lot of challenges. Findings reveals that the main challenge which is that 
of managing strike actions after difficulty in establishing a dialogue, has often been the case. It was therefore evident that strikes in most cases have often resulted to low employee-performance.

In trying to understand the challenges the drivers' union face in carrying out their daily activities as per the study, a leader of a drivers' trade union indicated as some of the challenges they face, inadequate managerial capacity, extortion from the security forces and insecurity in the town on a daily basis. To him, it is therefore important for the union to strive as part of their objective, to lobby for more changes that will favour their members and eventually improve on their job-performances. Another challenge earmarked by one of the members interviewed was cantered on how non-members are represented; to him it has caused a lot of problems as in most cases non-members who are drivers get into problems and turn to the union for help. He however insisted that though some unions do not come to the aid of non-members, it is a responsibility on the side of the trade union to come to the assistance of non-members. Notwithstanding, the non-members are usually schooled on the importance of belonging to a union and eventually some do see the need to adhere.

\section{Understanding the Core Strategies Used by Unions to Promote the performance of employees Cameroon}

The leader of drivers' union established that one of the major strategies used is when union members are mobilised for collective action in situations where negotiations have failed. He emphasized on the fact that trade unions play a dual role of protecting members and ensuring that they work hand in hand with management in order to boost high performance.

In an attempt to understand the core strategies, one of the teachers trade unions use a good number of strategies which are building teamwork strategies, empowering workers through seminars, coordinating the teaching activities, and promoting and protecting the rights and socioeconomic interests of union their members. These according to the study are the core founding objectives as they bring members together to fight for a common interest.

Another core strategy employed by one of the unions as cited by a leader has been employing lobbying groups through the influence of Political figures or what is called engagement of trade unions in political affairs, 
The Impact of Trade Unions on Employee Performance in Cameroon: Teachers' and Drivers' Unions Cases

which impacts employee-friendly laws. This to him is to ensure that labour unions have political powers so that they pressure the state to make or reform labour and trade laws, which are employee-friendly; thus, enhances performance.

\section{The Anglophone Crisis in Cameroon: A Result of Trade Unions Request for Reforms}

What has become a full-blown armed conflict within English-speaking regions of Cameroon started as strike actions following grievances by members of teachers and lawyer's trade unions. Considerable number teachers and lawyers in English-speaking regions of Cameroon decided to protest, reason being that they considered that the regime was marginalizing them by forcing the use French language on their courts and schools. As protest actions continued, more than 100 activists were arrested, which further escalated the protests. As a response, the administrative authorities of Cameroon formed a bureau to discourse with representatives of the CACSC. The representatives of the CACSC went to the dialogue with a set of demands ranging from reforming the legal and educational systems to proposing a change to the Federal system of government. The outcomes of the dialogue were unfruitful and consequently the government declared the CACSC illegal, and its leaders were arrested. The problem got worse as secessionist groups emerged seeking for separation from the Republic of Cameroon to form their own state called Ambazonia. Since then, the affected regions have seen repeated episodes of armed conflicts between secessionist and government forces. Schools were interrupted and frequent ghost towns declared in the North West (NW) and South West (SW) regions of the country. This equally drastically affected drivers trade unions, as they were under pressure from government to work on ghost town days declared by the secessionists. Several drivers' cars were burnt, and some lost their lives as a result of failure to comply with either party.

This crisis in Cameroon illustrates the challenging yet necessary role trade unions play in improving employee performance and reforming systems as a whole. These trade unions in Cameroon applied several strategies including organizing, collective bargaining, alliance building and action to push the government to bring about reforms that go a long way to improve employee performance. What started as peaceful protests quickly escalated 
and two major dialogues have been organized in attempts to solve the problems. The second, which was a national dialogue organized by the president of Cameroon, led to major reforms and many of the demands earlier made during the first dialogue by the CACSC were granted. What happened since 2016 is not very different from an earlier drivers' trade unions strike of 2008 that resulted from increasing fuel prices. Without trade union intervention the government or employers are not motivated enough to make reforms that improve systems and employee performance. According to a leader of a teachers' Trade Union in the South West Region of the country, the present Anglophone crisis in Cameroon is evidence of how strikes can affect employee performance and the entire system if not handled effectively. It is therefore important to note that when trade union representatives fail to negotiate with the administration, strikes are the next preferred alternatives. In most cases, resolutions after the strike enhance employee performance and in some cases it reduces.

\section{CONCLUSION}

We investigated the role played by trade unions in promoting employee performance in Cameroon, with emphasis on teachers and drivers' unions. There is a general understanding that trade unionism influences union members even in their daily operations. This fact added impetus for this study. The specific objectives of the research are assessing reasons for joining a trade union, core mandates and strategies used by trade unions to promote employee-performance and the effect of trade unionism on improved employee-performance.

Our results presented that the main reason of joining teachers and drivers trade unions in Cameroon is for the protection of workers' rights. The main strategies used by trade unions are organising, collective bargaining, alliance building and action. It is also revealed that trade unions have as core mandates the advocacy and protection of the rights and the socio-economic interest of their members. Furthermore, age group, level of education and the rating of strength of trade union are statistically significantly associated with improved employee-performance. The interviewed trade union executives said that their unions play an instrumental role in employee-performance. They, however, noted that the key challenges with teachers and drivers' unions in Cameroon are the wages, working 
conditions and legal protection. We can conclude that trade unions play a major role as they embark on helping employees to get their demands and improve on their job performance. Results from interviews and questions made it known that employees always involve themselves in trade union activities as part of their job requirements. Workers have different reasons for adhering into trade unions. For Cameroon, the research revealed that the objective of their adherence is for the protection of members rights and also for collective bargaining.

It is anticipated that the results of this research will give a better comprehension of the nature of the relationship between trade unionism and employee performance. Thus, the techniques on how employeeperformance can be improved by trade union activities and how expectations of the respondents can be rendered depending on the findings of the research. 


\section{REFERENCES}

[1] Aziz, A. A. (2010). The Extent to Which Labor Unions Can Influence Human Resource Practices in Bahrain, Master's thesis, Open University Malaysia.

[2] Ash \& Seago, (2004). The effects of Registered Nurses' Unions on Heart-Attack Mortality. Industrial and Labour Relations Review 57(3).

[3] Jepkorir, B. M. (2014). "The Effect of Trade Unions on Organizational Productivity in the Cement Manufacturing Industry in Nairobi," School of Business, University of Nairobi.

[4] Budd, John W. \& Bhave, Devasheesh. (2008). "Values, Ideologies, and Frames of Reference in Industrial Relations", in Sage Handbook of industrial Relations, Sage.

[5] Clark, A. E., Kristensen, N. \& Westergard-Nielsen. (2006). Job Satisfaction and Coworker.

[6] Devinatz, V. G. (2013). The Crisis of U.S. trade unionism and what needs to be done. Labour Law Journal, 64(1), 5-19.

[7] Freeman, R. B. \& J. L. Medoff (1981). "The Impact of the Percentage Organized on Union and Nonunion Wages", Review of Economics and Statistics, 63, 561-572.

[8] Gunderson (2005). Two faces of union voice in the public sector/ SpringerLink; https://link.spinger.com

[9] Hoxby (2001). Trade Union Membership and Influence 1999-2009; centre for Union studies Uk, cep.Ise.ac.uk.

[10] Jones, Derek, \& Takao Kato. (2005). "The Productivity Effects of Employee Stock-Ownership Plans and Bonuses: Evidence from Japanese Panel Data." American Economic Review 85 : 391-414.

[11] McNicholas, C. L., Rhinehart, M Poydock, H Shierholz \& D Perez (2020). "Why unions are good for workers-especially in a crisis like COVID-19: 12 policies that would boost worker rights, safety, and wages". Economic Policy Institute Report. 
The Impact of Trade Unions on Employee Performance in Cameroon: Teachers' and Drivers' Unions Cases

[12] Mbide Charles Kude, (2014). "Trade Union Freedom of Association and Collective Bargaining" The Cameroon Experience: The Evolution of Trade Unionism and the Prospects for Alternatives to the Labour Question.

[13] Morikawa, M. (2010) Labour unions and productivity: An empirical analysis using Japanese firm level data. Labour Economics 17(6): 10301037

[14] Nkirote, N. \& Kiiru, D. (2018). Influence of selected trade unions activities on performance of public universities in Kenya. International Academic Journal of Human Resource and Business Administration, 3(4), 174-206.

[15] Trades Union Congress (TUC) - Rosa Luxemburg Foundation (RLF), "Trade Unions and Industrial Relations in Ghana", 2012. 